\title{
Reducing of Fraud Cases of Illegal Financial Technology Peer To Peer Lending (Islamic Economic Perspective)
}

\author{
Basrowi $^{1}$, Pertiwi Utami ${ }^{2}$ \\ \{basrowi2018@gmail.com ${ }^{1}$, utamipertiwi89@gmail.com ${ }^{2}$ \} \\ ${ }^{1,2}$ Postgraduate Student of Sharia Economics Study, Universitas Islam Negeri Raden Intan Lampung, \\ Indonesia
}

\begin{abstract}
The objective to be achieved through this research is to find out the magnitude of the role of Islamic financial education and financial literacy in reducing the number of fraud cases of illegal financial techology peer to peer lending. The method used in this research is the quantitative documentary method. Data is collected using the documentation method, obtained from official data released by the Financial Services Authority of the Republic of Indonesia, Bank Indonesia, and official documents from related formal institutions available on the website, which are open access, which can be downloaded by everyone. Data was taken starting in 2014 since fintech began to develop rapidly. Data were analyzed using quantitative descriptive analysis in particular percentages. The results of data analysis show that, financial education and financial literacy that have been carried out by OJK and BI and other authorized parties have not been able to reduce the number of cases of illegal peer to peer lending Fintech fraud. In the future, it is expected that financial education and financial literacy can increase public awareness of illegal fintech advertisements and offers, which in turn can reduce cases of illegal fintech fraud.
\end{abstract}

Keywords: fraud, education, literation, financial, technology, sharia, peer to peer lending

\section{Introduction}

The financial behavior of the people, especially Muslims in Indonesia, can still be said to be not fully in accordance with Islamic values. The reason is due to the weak quality of financial education and the low financial literacy received by the public. Ardila explained, "The Indonesian Consumers Foundation (YLKI) has received more than 50 online credit complaints."[1] "Most of the complaints made are by way of charging up to an unclear system of calculating interest and penalties. 500 cases from January to early March 2019.’[2] This fact has made it clear that the implications of usury and bad financial behavior have a negative effect on the economy of the community.

The Jakarta Legal Aid Institute (LBH) states that, "It received 3,000 complaints from residents who were victims of online loans as of February 2019."'[2] Another fintech mode is billing not only to borrowers, but all family members and two contact numbers used as guarantors. Seeing this condition, illegal peer to peer lending is very dangerous to the community. Until now, "There are only 127 peer to peer lending registered and supervised by the OJK, but the number of finteches in circulation is very large, namely 1,087 illegal finteches." [2] All illegal fintechs that are blocked by the Ministry of Communication and Information always change the URL address (website) and change applications in the Google Playstore. Until June 2019, “The number of loans approved by Fintech organizers was Rp 44.8 trillion. This condition grew by around $97.68 \%$ from last year's position in December 
2018 which was only Rp 22.66 trillion. The number of accounts opened through fintech peer to peer lending as of June 2019 was $9,743,679$ accounts."[3].

The next problem is, " With the growth of Indonesian fintech lending, unbankable segmented people choose fintech. Proven in the last 5 years fintech has increased significantly every year. But from the significant increase there are some problems that befall these finteches."[4] Fintech Peer-To-Peer Lending that is not registered or has a business license from OJK in accordance with POJK Number 77 / POJK.01 / 2016 that has the potential to harm the public in 2018 is 404 entities, while in 2019 there are 826 entities.[5] Some of the problematic fintechs come from abroad. "OJK noted $15 \%$ of the 1,230 problematic fintechs came from the United States (US), $8 \%$ from Singapore, $4 \%$ from China, $2 \%$ from Malaysia, and 22\% came from Indonesia."[6]

Atkinson and Messy stated that, "The recent economic crisis has led to the recognition that the lack of financial literacy among individuals has had a tremendous negative effect on the economy."[9] Communities who behave in a consumptive manner and lack the habit of saving are still quite dominating in Indonesia, for example, can be seen from the high use of Fintech services and online shopping.[7]

Islamic financial literacy turned out to be able to influence economic factors in Indonesia. Those who have good socio-economic characteristics are those who have good financial knowledge, financial attitudes and financial behavior.[8] Studies conducted by students explain that Islamic financial literacy is needed in personal financial management.[9] In addition, education in improving sharia financial literacy requires halal literacy business management such as MSMEs.[10] However, until now the construction of Islamic financial literacy itself does not have the dimensions and indicators that are indispensable as parameters for measuring the level of community financial literacy in various groups.[11] Therefore, the importance of Islamic financial education, including how to guide to ensure individual and social welfare.[12] This research is expected to encourage Muslims to become more literate in Islamic finance and observe Islamic financial behavior.

Fintech Syariah claims to abide by Sharia principles in their clever mechanism and contract that is without Maysir, Gharar, and usury (Magrib). The Ulama agree that Fintech is a Maslahah for the benefit of humanity.[13] The obstacles currently faced by Fintech Syariah are the lack of policy instruments that safeguard Fintech's work processes, and the availability of human resources.[14] Fintech Syariah is present in the community to provide convenience benefits for its users. Assist them in solving financial problems and provide financing to run a business.[15]

The novelty of this research lies in the concrete steps that can be applied to reduce the number of cases of fraud committed by illegal fintech, in order to improve the welfare of the community. Another novelty of this study, namely the existence of important recommendations about financial education that can be directly applied in improving public literacy, which in turn can reduce the number of cases of fraud fintech peer organizers to peer lending.

\section{Theoritical Review}

Financial behavior studies the application of psychology to finance, focusing on: "1) the characteristics of financial behavior that can affect financial problems both individuals and companies; 2) financial behavior can affect trading and market prices, 3) the role of arbitration and the flow of wealth between investors who are more rational and less rational; 4) strategies to spread and develop financial ideas."[16]. 
"Research that focuses on the use of financial information and its characteristics often assumes that financial information itself is neutral, impartial, and free of value." [17] Financial education is the skill to apply these concepts and translate them into effective and appropriate use of financial services; and can change people's attitudes towards managing financial resources.[18] The scope of financial education involves, "The collaboration of various stakeholders as well as the identification of national leaders or agencies / councils." [18] "Financial education programs provide individuals with the skills and means to use financial resources more effectively and to choose financial services and products that suit their needs."[8]

In modern financial practices such as Fintech Sharia, "Its development is based on the concept of the Islamic Economic System using risk sharing as the main method and does not include financing on a fixed basis and specified returns."[9] "Islamic education is needed in Islamic financial education. Because in essence, the philosophical thinking of Islamic education is an effort to move all the psychological potential of humans, such as thoughts, intelligence, will, feelings and observations of the five."[19] From the basic Islamic law of Al Qur'Aan Surah Al Qaashash verse 77, it can be understood that the effort to improve Islamic financial education is a must for those who want the welfare of the.

"Islamic financial literacy can be defined as the ability to understand finance based on sharia compliance. This should be an issue of concern to Muslim students."[9] There are two main principles namely shar'i and the tabi'i principle. Sharia principles are principles that are based on the Qur'an and al-Hadith. Sharia principles must be used in Islamic financial activities and transactions.[9]

\section{Research Methods}

The method used in this research is the quantitative documentary method. Data collected using the documentation method. Data is obtained from official data released by the Financial Services Authority of the Republic of Indonesia, Bankof Indonesia, and official documents from related formal institutions available on the website, which are open access, which can be downloaded by everyone. Data collected from 2016 since fintech began to develop rapidly until August 2019. To improve the validity of the data checks, re-checks, and cros checks are performed. Cros check is done by comparing data from one agency with other agencies. Quantitative documentation data were analyzed by percentage analysis, while qualitative narrative data were analyzed by using analysis methods from Meleong [20] which included data collection, data classification, data filtering, and drawing conclusions.[21]

\subsection{Research and Discussion}

\subsubsection{Financial Education and Financial Literation has been done by OJK and BI}

Statistics of fintech lending until June 2019 as reported by OJK can be observed through the following table.[22]

Table 1. Statistics of fintech lending until June 2019

\begin{tabular}{rrrr}
\hline No & Deskription & June 2019 & \% $\Delta$ June 2019 ytd \\
1. & Number of Accumulated Lender Accounts (Entity Unit) & & \\
& Aggregate (Total) & 498.824 & $140,39 \%$ \\
\hline
\end{tabular}




\begin{tabular}{|c|c|c|c|}
\hline No & Deskription & June 2019 & $\% \Delta$ June 2019 ytd \\
\hline \multirow[t]{2}{*}{2.} & Total Accumulated Borrower Accoun & & \\
\hline & Aggregate (Total) & 9.743 .679 & $123,51 \%$ \\
\hline \multirow[t]{2}{*}{3.} & Amount Accumulated Lender Transa & & \\
\hline & Aggregate (Total) & 23.988.288 & $172,86 \%$ \\
\hline
\end{tabular}

The number of Fintech investor accounts is 498,824 accounts. Borrower (Unit of Entity) Accumulated Accounts Number of 9,743,679 accounts, Amount of accumulated loans of IDR $44,805,833,927,177$. The number of lenders accumulated in the July-October 2018 Lender Account experienced a significant increase, from 135,025 lenders in July 2018, growing to 182,895 lenders in October 2018., an increase of 47,870 lenders (35.45\%).

At present there are still many people who have not been touched by banking services (unbanked). The bank has only been able to provide services to $67.8 \%$ of people in Indonesia. This means that there are still around $32.2 \%$ of the adult population in Indonesia who have not yet received banking services.[22] The financial inclusion index (IKI) in Indonesia until 2018 only reached $67.8 \%$, so it needs to be improved through Presidential Regulation No. 82 of 2016 concerning the national strategy for financial inclusion by forming a national board of financial inclusion.[23] Financial inclusion data can be tabulated as follows.

Table 2. Data for financial inclusion in 2011-2019

\begin{tabular}{clc}
\hline Year & \multicolumn{1}{c}{ Financial Inclusion rate (\%) } & \multicolumn{1}{c}{ information } \\
2011 & 20,0 & -- \\
2012 & No official data was recorded & -- \\
2013 & 36,0 & In two years it increased $16 \%$ \\
2014 & 59,7 & In one years it increased $23,7 \%$ \\
2016 & 67,8 & In two years it increased $8,1 \%$ \\
$2017-$ & No official data was recorded & -- \\
2018 & & \\
2019 & 75 (pediction) & Expected to increase in 1 year 7,7\% \\
\hline
\end{tabular}

When viewed from the type of financial education programs conducted by Bank Indonesia, BI uses long-term and short-term programs. First, the long term, among others, increases financial inclusion to touch the figure above $90 \%$. Second, the short-term program is conducting financial education, financial services in the government sector, consumer protection, conducive policies and regulations, infrastructure and financial technology.[23] OJK is in the process of financial education so that people are not caught up in illegal online loans when borrowing from fintech peer to peer lending, namely 1) checking fintech entities registered and supervised by the Financial Services Authority, and 2) considering fintech that has been registered and supervised by the OJK.[25]

Detik Finance 2019 in the process of financial education released the characteristics of illegal fintech: 1) does not have official permission, 2) there is no clear identity and office address, 3) lending is very easy, 4) interest information and fines are unclear, 5) unlimited interest, 6) unlimited fines, 7) unlimited time collection, 8) access to all data on mobile phones, 9) threats of terror of violence, insults, defamation, distributing personal photos / videos, 10) no complaint service.[26] Bank Indonesia currently has a financial education and 
literacy program which includes: "1) digital financial services, 2) electronic money registration, 3) information systems for farmers and migrant workers, 4) database development by connecting customer telephone numbers with account numbers (finacial identitu number / FIN)."[24]

OJK has taken various educational steps in order to increase public literacy on financial technology. Various educational steps taken include: 1) through its official website having carried out various education to all people about the importance of raising awareness of the dangers of illegal fintech snares, 2) publishing legal Fintech names, 3) publishing illegal fintech names, 4) conducting service plans society about wisely choosing fintech lending and borrowing, 5) reporting examples of various illegal fintech fraud cases, so that people are more alert in utilizing fintech, 6) educating the public about the characteristics of illegal fintech.[6]

As for some of the educational steps as a precautionary measure taken by the Investment Alert Task Force for illegal online loans are by: "1) announcing illegal Fintech Peer-To-Peer Lending to the public, 2)" As well as educating and socializing to the community in a sustainable manner to use fintech legal ones.[27] In providing education, "Customers who want to complain or want to get information can be through customer service through the telephone number 150505 on Monday-Friday working days and working hours of 8:00 to 17:00 WIB. It could also be via email complaint@afpi.or.id or through the website www.afpi.or.id."[28]

\subsubsection{Various Efforts to Reduce Fintech Provider Fraud Cases}

The curative efforts or actions taken by OJK in order to reduce fraud by fintech organizers include: (1) OJK has asked Google to close access to the makers of this type of loan application. But, that step is not easy to do, because Google supports the application and system of fintech businesses that are open source. (2) The Financial Services Authority (OJK) and the Indonesian Police Criminal Investigation Agency who are members of the Task Force for Handling Alleged Unlawful Acts in the Field of Collecting Community Funds and Investment Management have also carried out various legal action against illegal fintech operations.[7]

The action measures that have been taken include: 1) submitting blocked websites and applications regularly, 2) severing financial access from Fintech Peer-To-Peer Lending by submitting an appeal to banks to refuse opening an account without opening an account OJK recommendations, 3) confirm OJK for existing accounts allegedly used for illegal Fintech Peer-To-Peer Lending activities, 4) request Bank Indonesia (BI) to prohibit the Fintech Payment System to facilitate the Fintech Peer-To-Peer Lending, 5) submit an information report to the Criminal Investigation Police for the process of law enforcement, and 8) request an increase in the role of the Joint Funding Fintech Association (AFPI) for handling Fintech Peer-To-Peer Lending." [10]

Obstacles in educational programs and financial inclusion include: 1) fraud committed by investment actors, thus making the community turn in the wrong direction about a financial product; 2) features in fintech only highlight the benefits of not showing the risks, costs, rights and obligations, 3) regulators whose role is to oversee the existence of illegal fintech is still very weak.[27] 
Table 3. the number of fictech lending in Indonesia

\begin{tabular}{llll}
\hline \multicolumn{1}{c}{ Year } & \multicolumn{2}{c}{ total } & \multicolumn{1}{c}{ information } \\
2017 & 36 & 57 & -- \\
January 2018 & 89 & 404 & illegal finteches is increasing 347 \\
December 2018 & 91 & 826 & illegal finteches is increasing 422 \\
April 2019 & 99 & 826 & -- \\
May 2019 & 101 & 1230 & illegal finteches is increasing 404 \\
July 2019 & 127 & 1287 & -- \\
5 August, 2019 & 127 & 1369 & illegal finteches is increasing 182 \\
8 August, 2019 & 127 & 1512 & illegal finteches is increasing 143 \\
\hline
\end{tabular}

Source: OJK, BI, and Media online 2017-2019

As a concern, because, 1) Interest from fintech P2P Lending is very higher $(0.8 \% / \mathrm{min})$. the majority of cases, if he borrowed 2 million within 90 days it has become 4 million. this means interest becomes 30 percent / month, 2) Profider use ID illegally. at registration, fintech asks the user to fill in all data, but this data is used incorrectly, 3) If there is a bad credit. All of family memmbers as guarantor and use debt collector agent.

According to Muzdalifa, et.al another risk is the presence of cybercrime in the form of breaking into financial transactions of fintech users.[29] Risks experienced by the organizers, namely the existence of bad credit, amounting to 0.99 (December, 2018); of 1.28\% (January 2019), and 3\% (June 2019). [30]. The bad credit according to He et.al was mostly caused by the weakness of the contral function during data processing and risk management.[31] According to Kolesovo \& Girzheva [32] fintech has made the banking system more vulnerable to cyber threats and exposed a large amount of confidential data to be misused.

Table 4. Cases of fraud reported by fintech users

\begin{tabular}{cclc}
\hline Period of complaint & Total cases & Report recipient & Etc \\
January-February 2019 & 50 & YLKI & -- \\
January-December 2018 & 500 & $\begin{array}{l}\text { Fintech joint } \\
\text { Funding } \\
\text { Association (AFPI) } \\
\text { Legal aid }\end{array}$ & $\begin{array}{l}\text { 14 violations of human rights } \\
\text { Human rights } \\
\text { Threat, slander, sexual harassment, } \\
\text { and fraud were reported by 781 } \\
\text { custumers }\end{array}$ \\
& 1.330 & & \\
January-August 2019 & 3.000 & Legal aid &
\end{tabular}

"The average user applies for a very small loan. As many as $51.24 \%$ of the total complaints filed for loans in the amount of Rp1 million to $\mathrm{Rp} 2$ million. Then as much as $33.33 \%$ borrowed around Rp. 0 - Rp1 million.[1] Referring to the report, $36.07 \%$ of these complaints came from the DKI Jakarta area, 27 24\% from West Java, 9.8\% from Banten, 1.35\% from East Kalimantan, 7.10\% from Central Java, 8 , 3\% from East Java, $81.28 \%$ from Bali and North Sulawesi $1.58 \%$. As many as $7.47 \%$ came from other regions such as North Sumatra, West Sumatra, Riau Islands, Gorontalo, West Nusa Tenggara, East Nusa Tenggara and others.'"[33] 


\subsubsection{The doctrine of Muamalah in Reducing Fraud Acts}

"The creation of a peer-to-peer platform has not been fully utilized in the Muslim community segment. Whereas the benefits can be felt quite a lot, including: 1) accelerating the rate of financial inclusion by attracting untapped segments of the Muslim community, 2) enabling direct investment in small projects, and 3) paving the way for finance in accordance with Islamic principles.'[34]

Until now the Financial Services Authority and the National Sharia Council of the Indonesian Ulema Council (Fatwa No. 117 / DSN-MUI / II / 2018 Regarding Information Technology Based Financing Services Based on Sharia Principles). "All economic problems must be subject to and obey the rules in the principles of Shari'a." [35] As the basic values in the Islamic Economic System, namely 1) justice that upholds the value of truth, honesty, and courage and consistency in the truth that is true, 2) Responsibility for the welfare of the universe as a mandate entrusted to the caliph who is none other than humanity.[36]

The National Sharia Council fatwa relating to Fintech basically permits, only it limits to sharia-based fintech. Fintech chosen should be legal fintech which is always subject to the teachings of the Koran and Assunah. The risk of financial transactions being 'online' according triggers fraud and forgery.[25] For this reason, Islamic legislation places several methods to resolve this issue through pledges, testimonies, expert opinions and oaths.

\section{Conclusion}

Based on the description above it can be concluded that:

1. Financial education efforts undertaken by OJK in the context of increasing public literacy have not been able to increase public understanding and prudence in choosing and utilizing illegal peer-to-peer financial lending platform technology. In the future, it is hoped that the education carried out by the parties mentioned above will be able to increase public literacy which will have an impact on increasing the level of community awareness in utilizing fintech, which in turn can reduce the number of fraud committed by illegal fintech.

2. The role of Islam in regulating muamalah, especially in the field of technology-based lending and borrowing which has been fatwa by the National Sharia Council, is very clear and detailed, that fintech is permissible, only that it must be careful in choosing fintech. The chosen Fintech should be legal and use sharia principles in managing and conducting its business. The chosen fintechs should not be illegal fintechs that apply high interest rates, and do not apply the Islamic concept.

Acknowledgment. Thank you to the Postgraduate of Sharia Economics Study, Universitas Islam Negeri Radin Inten Lampung, who helped in the planning, actuating, organizing, and finalization of this research so that it could be published.

\section{References}

[1] Ardila, N.: YLKI Terima 50 Aduan Pelanggaran Fintech Sejak Januari 2018. 2018.

[2] Indonesia, C.: Asosiasi Catat 500 Pengaduan Nasabah Pinjaman Online (2019)

[3] Halim, D.: Sejak 2018, OJK Klaim Tutup Ilegal (2019)

[4] Di Balik Uang 'Panas' Pinjaman Online Ilegal (2019)

[5] Hastuti, R. K.: Hati-hati ! 143 Fintech Ilegal Menghantui Masyarakat Indonesia (2019) 
[6] Indonesia, C. Perhatian! Ini Daftar Nama 143 Fintech Ilegal (2019)

[7] Atkinson, A. and Messy, F.: Measuring Financial Literacy: Results of the OECD / International Network on Financial Education (INFE) Pilot Study. OECD Working Papers on Finance, Insurance and Private Pensions, OECD Publ., no. 15, pp. 1-73 (2012)

[8] Cohen, L.: Research methods in edu- cation Routledge, vol. 42, no. 5. New York \& London (2011)

[9] Setyawati, I. and Suroso, S.: Sharia Financial Literacy And Effect On Social Economic Factors (Survey On Lecturer In Indonesia ), Int. J. Sci. Technol. Res., vol. 5, no. 02, pp. 92-102 (2016)

[10] Arifin, M.: Filsafat Pendidikan Islam Edisi Revisi. Bumi Aksara, Jakarta (2017)

[11] Tibawi, A. L.: Islamic education: its traditions and modernization into the Arab national systems. Luzac, London (1972)

[12] Abdul Mujib, J. M.: Ilmu Pendidikan Islam. Kencana Prenada, Jakarta (2008)

[13] Rahim, N. F., Bakri, M. H., and Siti, N. Y.: Fintech and Sharia Principles in Smart Contracts, in FinTech as a Disruptive Technology for Financial Institutions, no. 2017. pp. 207 (2019)

[14] Rusydiana, A. S.: Developing Islamic Financial Technology In Indonesia, Hasanuddin Econ. Bus. Rev., vol. 2, no. 2, pp. 143-152 (2018)

[15] Wijayanti, D. M.: Syariah Fintech: Positive Innovation in Consumer Perspective, in Proceding International Seminar Academic Network On Competition Policy, pp. 101120 (2017)

[16] Hirshleifer, D.: Behavioral Finance, e-book, vol. 7, pp. 1-69 (2014)

[17] Hellmann, A. and Hellmann, A.: The Role of Accounting in Behavioral Finance, J. Behav. Exp. Financ., vol. 9, no. 10, pp. 39-42 (2016)

[18] OECD (Organization for Economic Co-operation and Development): Advancing National Strategies for Financial Education. Russia's G20 Presidency and the OECD (2013)

[19] Wahyuny, I. N.: Efisiensi organisasi pengelola zakat nasional dengan metode data envelopment analysis, J. Islam. Econ., vol. 2, no. 1, pp. 1-12 (2016)

[20] Obaidullah, M.: Islamic Financial Services (2016)

[21] Moleong, L. J.: Metodologi Penelitian Kualitatif ( Edisi Revisi ). Rosda Karya, Bandung (2017)

[22] Statistik Fintech Lending Periode Juni 2019. pp. 2321 (2019)

[23] Tren fintech dan perbankan (2017)

[24] Keuangan Inklusif: Apa, Mengapa, Bagaimana, \& Siapa (2019)

[25] Financial Services Authority Regulation Number 77/PJOK.01?2016 concering on Information Technology-Based Money Lending and Borrowing Services. pp. 1-16 (2016)

[26] Laucereno, S. F.: Google Pun Sulit Berantas Fintech Abal-Abal di RI (2019)

[27] Heriani, F. N.: Tak Semua Aduan Fintech Ilegal Dapat Ditindaklanjuti Satgas (2019)

[28] Sugianto, D.: Merasa 'Ditipu' Fintech? Adukan ke Sini (2019)

[29] Muzdalifa, I., Rahma, I. A., and Novalia, B. G.: FinTech's Role in Enhancing Inclusive Finance in UMKM in Indonesia (Sharia Financial Approach), J. Masharif al-Syariah J. Ekon. dan Perbank. Syariah, vol. 3, no. 1, pp. 1-24 (2018)

[30] OJK.: Penyelenggara Fintech Terdaftar dan Berizin di OJK per 31 Mei 2019 (2019)

[31] He, D., et. al.: Fintech and Financial Services. Initial Considerations (2017)

[32] Kolesova I. V. and Girzheva Y. S.: Impact of Financial Technologies on the Banking 
Sector. KnE Soc. Sci., vol. 3, no. 2, pp. 215-220 (2018)

[33] Aldila, N.: Aduan Masyarakat: Kasus Fintech Lending Membengkak (2018)

[34] Umar, A. O. and Ali, S. N.: Fintech in Islamic Finance: Theory and Practice, no. July. Rotledge (Taylor \& Francis Grouup), London and New York (2019)

[35] Hills, R. J.: Toward a Science of Organization . by R . Jean Hills Review by : Harry Cohen, vol. 47, no. 4. Oxford University Press (2014)

[36] sRobertson, R. and Turner, B. S.: Talcott Parsons and Modern Social Theory - An Appreciation. Rral Socailogy, Vol. 6, no. 4, pp. 539-558 (1989) 